\title{
Pain assessment in critical patients using the Behavioral Pain Scale
}

\author{
Avaliação da dor em pacientes críticos por meio da Escala Comportamental de Dor
}

Laudice Santos Oliveira ${ }^{1}$, Maiara Pimentel Macedo ${ }^{1}$, Stefany Ariadley Martins da Silva ${ }^{1}$, Ana Paula de Freitas Oliveira1, Victor Santana Santos ${ }^{2}$

\section{ABSTRACT}

BACKGROUND AND OBJECTIVES: The sensation of pain is essential for life, and its assessment in critical non-contacting patients can be performed using validated scales. The Behavioral Pain Scale is a highly accurate tool that has been widely used in this group of patients. This study aimed to describe and characterize pain and the use of analgesia in the emergency or intensive care service.

METHODS: This was a cross-sectional study with a quantitative approach with 67 critically ill patients unable to verbalize their pain perception, who were hospitalized in the emergency service or Intensive Care Units of a public hospital in Vitória da Conquista, Bahia from April to July 2017. Clinical and epidemiological data were collected using the medical record and then applied to the Behavioral Pain Scale for pain assessment.

RESULTS: There was a predominance of male patients (47/70.1\%). Three groups were identified based on the use of sedatives and analgesics: patients taking sedatives and analgesics combined, only analgesia, and those without any sedation or analgesia. We observed ascending Behavioral Pain Scale scores in all groups during tracheal suction, but the same did not occur with the physiological parameters.

CONCLUSION: The study proposes the adoption of pain assessment scales in critical patients, such as the Behavioral Pain Scale, as well as the use of protocols for analgesia management, and consequently improve the quality of care and patient's recovery.

Keywords: Emergency medical services, Intensive Care Units, Pain, Pain management, Pain measurement.

Laudice Santos Oliveira - (Dhttps://orcid.org/0000-0002-8747-4625;

Maiara Pimentel Macedo - (Dhttps://orcid.org/0000-0002-0611-6034;

Stefany Ariadley Martins da Silva - Dhttps://orcid.org/0000-0001-9637-4485;

Ana Paula de Freitas Oliveira - (Dhttps://orcid.org/0000-0002-7410-1563;

Victor Santana Santos - (Dhttps://orcid.org/0000-0003-0194-7397.

1. Universidade Federal da Bahia, Instituto Multidisciplinar em Saúde-Campus Anísio Teixeira, Departamento de Enfermagem, Vitória da Conquista, BA, Brasil.

2. Universidade Federal de Alagoas, Departamento de Enfermagem, Arapiraca, AL, Brasil.

Submitted on May 10, 2018.

Accepted for publication on February 19, 2019.

Conflict of interests: none - Sponsoring sources: none.

Correspondence to:

Rua Hormindo Barros, 58, Quadra 17, Lote 58 - Bairro Candeias

45.029-094 Vitória da Conquista, BA, Brasil.

E-mail: enf.lais@gmail.com

(C) Sociedade Brasileira para o Estudo da Dor

\section{RESUMO}

JUSTIFICATIVA E OBJETIVOS: A sensação de dor é essencial para a vida. Sua avaliação em pacientes críticos não contatantes pode ser realizada por meio de escalas validadas. A Behavioral Pain Scale é um instrumento de aplicaçấo, com elevada acurácia, e que tem sido amplamente utilizada neste grupo de pacientes. Este estudo objetivou descrever e caracterizar a dor e o uso de analgesia no serviço de urgência e cuidados intensivos.

MÉTODOS: Trata-se de um estudo transversal com abordagem quantitativa, realizado com 67 pacientes críticos impossibilitados de verbalizar a percepção de dor, os quais estavam hospitalizados na área vermelha do pronto-socorro ou nas Unidades de Terapia Intensiva de um hospital público de referência em Vitória da Conquista, Bahia no período de abril a julho de 2017. Dados clínicos e epidemiológicos foram coletados utilizando-se o prontuário e em seguida foi aplicada a Behavioral Pain Scale para avaliação da dor.

RESULTADOS: Houve predomínio de pacientes do sexo masculino $(47 / 70,1 \%)$. Foram identificados três grupos com base no uso de sedativos e analgésicos: pacientes em uso de sedoanalgesia, uso apenas de analgesia, e os que estavam sem sedação ou analgesia. Visualizou-se ascensão dos escores da Behavioral Pain Scale em todos os grupos durante a aspiração traqueal, porém o mesmo não aconteceu com os parâmetros fisiológicos.

CONCLUSÂO: O estudo apresentou como proposta a adoção de escalas de avaliação da dor no paciente crítico, como a Behavioral Pain Scale, bem como uso de protocolos de analgesia e manuseio, melhorando assim a qualidade da assistência prestada e a recuperação do paciente.

Descritores: Dor, Manuseio da dor, Mensuração da dor, Pronto-Socorro, Unidade de Terapia Intensiva.

\section{INTRODUCTION}

The sensation of pain is essential for life. Its perception is the result of multidimensional and personal experiences in the face of the various stimuli that result or not in tissue injury ${ }^{1}$. Therefore, the protocols of care recommend the evaluation of pain by health professionals during the assistance. In individuals who verbalized and have preserved cognition, pain measurement can be more easily reported because the individual is able to describe the pain he/she feels ${ }^{2}$. However, in critically ill patients who are under adverse conditions that prevent them from verbalizing the presence or absence of pain ${ }^{3,4}$ either by changes in the level of consciousness, the effects of sedative agents and/or the use of mechanical ventilation ${ }^{5}$, the measurement of pain can only be indirect. 
Some studies report that the observation of changes in physiological parameters may be a quick and simple method to infer pain $^{6-8}$. However, the use of physiological data alone is debatable, since several factors such as fear, anxiety and psychological stressors can influence this measurement ${ }^{6,7,9}$. Also, the absence of changes in the vital signs does not necessarily indicate the absence of pain ${ }^{10}$.

As the inability to report pain does not deny its existence and does not discard the right to adequate treatment ${ }^{11}$, when it is impossible to obtain the patient's self-report about the pain it is recommended to use observational scales ${ }^{12}$ that are based on the individual's physiological parameters and body expressions. Among the available scales to measure the pain in non-responsive patients, the most used by the health services is the Behavioral Pain Scale (BPS) because it is highly accurate and easy to apply to patients with severe pain ${ }^{13,14}$.

Knowing the level of pain of patients, whether critical or not, is essential to optimize comfort and minimize suffering ${ }^{15}$. In addition, effective and adequate pain control is associated with a reduction in mechanical ventilation time, shorter patient length of stay, and lower morbidity and mortality rates in intensive care units $(\mathrm{ICU})^{16}$. However, despite these benefits, pain assessment has been performed inadequately (or not performed) in some health services that provide care to critical patients, making it difficult to manage pain in these patients adequately ${ }^{17,18}$.

Given the above, the present study aimed to evaluate the pain and the use of analgesia in critically ill patients admitted to the emergency and intensive care services of a public reference institution in southwest Bahia.

\section{METHODS}

This is a cross-sectional and descriptive study with a quantitative approach, referring to critically ill patients admitted to the red area of the emergency room or to one of the two ICUs of a public reference hospital in Vitória da Conquista, Bahia, Brazil, between April and July 2017.

This hospital is located $519 \mathrm{~km}$ from the capital, Salvador, and it is a reference for 73 smaller cities with a population of approximately 1.7 million inhabitants ${ }^{19}$.

The sampling was non-probabilistic due to adequacy, with an estimated sample size of about $60-65$ patients. The calculation was based on an accuracy of $0.95 \pm 0.05$ of the Cronbach's alpha coefficient for a scale with three subscales.

All critical patients admitted during the study period, older than 18 years of age, of both genders, using mechanical ventilation, sedated and unarticulated, who were unable to report pain, and with a maximum stay time of $48 \mathrm{~h}$ were included. Patients in neurological protection, quadriplegic, who had received a neuromuscular blocker, who had peripheral neuropathy or suspicion of brain death, were excluded. These exclusion criteria were used not to include patients whose diseases or drugs could compromise the expression of pain behaviors.

After the written consent was signed by a responsible family member, duly trained research assistants, using the previously prepared data collection instrument, obtained the clinical and demographic data from the patient's medical records. The demographic information included age and gender. The clinical data included prior comorbidities, diagnosis, pharmacological prescription (use of analgesics and continuous infusion sedatives, given at regular intervals or if necessary). In addition, the information on the neurological assessment of each patient was obtained using the Glasgow Coma Scale, FOUR (Full Outline of Unresponsiveness), and the Richmond Agitation Sedation Scale (RASS), which are routinely used by professionals who work in the field of study.

The research assistants also collected information on the vital signs of each patient using a multimodal monitor during three moments of the study: at rest, during eye cleansing (EC) with gauze moistened in saline (considered a non-painful procedure) performed by the nursing technician and during the tracheal suction (TS) (considered a painful procedure) ${ }^{20}$ performed by the assistant physiotherapist. These procedures are already part of the patient care routine, so no additional procedure is required.

Simultaneously, the researchers applied the BPS validated in Brazil by Morete et al. ${ }^{14}$ (Table 1). The BPS has a total of 12 descriptors, distributed in 3 items (1. Facial expression, 2. Upper limbs, 3. Adaptation to mechanical ventilation) $)^{7,14}$ with results varying from 3 (absence of pain) to 12 (unbearable pain $)^{13}$. A score $>3$ indicates the presence of pain and $\geq 5$ indicates significant pain ${ }^{21}$.

Table 1. The Brazilian version of the Behavioral Pain Scale

\begin{tabular}{|c|c|c|}
\hline Items & Description & Score \\
\hline Facial expression & $\begin{array}{l}\text { Relaxed } \\
\text { Partially contracted (e.g., lowering } \\
\text { eyelid) } \\
\text { Completely contracted (eyes clo- } \\
\text { sed) } \\
\text { Facial contortion }\end{array}$ & $\begin{array}{l}1 \\
2 \\
3 \\
4\end{array}$ \\
\hline $\begin{array}{l}\text { Movement of the } \\
\text { upper limbs }\end{array}$ & $\begin{array}{l}\text { No motion } \\
\text { Partial motion } \\
\text { Full motion with finger flexion } \\
\text { Permanently contracted }\end{array}$ & $\begin{array}{l}1 \\
2 \\
3 \\
4\end{array}$ \\
\hline $\begin{array}{l}\text { Comfort with the } \\
\text { mechanical ventila- } \\
\text { tion }\end{array}$ & $\begin{array}{l}\text { Tolerant } \\
\text { Cough, but tolerant of mechanical } \\
\text { ventilation most of the time } \\
\text { Fighting with the fan } \\
\text { No ventilation control }\end{array}$ & $\begin{array}{l}1 \\
2 \\
3 \\
4\end{array}$ \\
\hline
\end{tabular}

The present study complies with the provisions of Resolution 466/12 and was approved by the Human Research Ethics Committee of the Multidisciplinary Health Institute, Anísio Teixeira Campus of the Federal University of Bahia under CAAE 65835917.6.0000.5556.

\section{Statistical analysis}

All information obtained was coded and inserted into a database. Then, we performed an exploratory analysis of the data through the calculation of absolute and percentage simple frequencies for the categorical variables. The normal distribution of the data set was checked using the Kolmogorov-Smirnov test. The ANOVA test was used to check the fluctuation of the 
parameters within the same group between the three moments of measurement of the values. The level of significance of the analysis was $5 \%(\mathrm{p}<0.05)$. The data were analyzed using the SPSS software version 20.0 .

Table 2. Demographic and clinical data of the patients included in the study. Vitória da Conquista, April to July/2017

\begin{tabular}{lc}
\hline Categorical variables & $\mathrm{n}(\%)$ \\
\hline Gender, male & $47(70.1)$ \\
Area, urban & $51(76.1)$ \\
Diagnostic classification & \\
Clinical & $49(73.1)$ \\
Trauma & $18(26.9)$ \\
Comorbidity & \\
Yes & $41(61.2)$ \\
Pharmacological scheme & \\
Prescribed sedation and analgesia & \\
Group 1 & \\
Group 2 & $31(46.3)$ \\
Group 3 & $18(26.9)$ \\
Pain assessment & $16(23.9)$ \\
BPS $\geq 5^{*}$ & \\
BPS $\geq 5$ (During TS) ** & $70(34.8)$ \\
Numerical variables & $61(91)$ \\
Age, median (IQI) & Mean (SD) \\
FOUR & $56(36-74)$ \\
Coma Glasgow scale & $6.2 \pm 3.63$ \\
RASS & $4.3 \pm 2.16$ \\
\end{tabular}

BPS = Behavioral Pain Scale; TS = tracheal suction; FOUR = Full Outline of Unresponsiveness; RASS = Richmond Agitation Sedation Scale; IQI = interquartile interval; Group 1 = sedation and analgesia; Group 2 = analgesia; Group 3 = no sedation or analgesia. Categorical data presented quantitatively and percentage, numerical data on average and standard deviation. ${ }^{*} 201$ observations, ${ }^{\star *} 67$ observations.

\section{RESULTS}

Sixty-seven patients were included in the study. Each of them was evaluated in three moments: a) at rest, b) eye cleansing (EC) and c) tracheal suction (TS); totaling 201 observations (67 patients versus three observations each). Patients were predominantly male $(47 / 70.1 \%)$, with a median age of 56 years (IIQ: 36-74), urban residents $(51 / 76.1 \%)$, with reports of pre-existing comorbidity (41/61.2\%). Most patients had a clinical diagnosis (49/73.1\%), followed by trauma (18/26.9\%) (Table 2).

After collection, three groups of patients were identified based on the use of sedatives and analgesics: G1, patients undergoing sedation and analgesia; G2, only using analgesia; and G3, without sedation or analgesia.

The majority of the patients were using analgesia associated with sedation $(31 / 46.3 \%)$, and midazolam and fentanyl were the most commonly used drugs. Patients undergoing sedation and analgesia were evaluated by RASS and had an average score of $-4.5 \pm 1.29$. Eighteen (26.9\%) were using analgesia alone, with fentanyl and dipyrone being the most prescribed analgesics. For these individuals, the neurological evaluation was performed using the FOUR scale in 28 patients with a mean of $6.2 \pm 3.63$; and Glasgow coma scale in six patients with a mean of $4.3 \pm 2.16$. Sixteen patients $(23.9 \%)$ were without analgesia or sedation. Of the 201 observations, in $70(34.8 \%)$ patients had a score of $\geq 5$ on BPS (Table 2).

Table 3 shows the variation of the physiological parameters in the three evaluation moments for the three groups identified. Variation was observed in the three evaluation groups in all the physiological parameters with the interventions, except in temperature.

Table 4 shows the variation of the BPS scores. In all three groups of patients, a significant fluctuation was observed in all scores on the scale, especially between at rest and tracheal suction.

Table 3. Variation of the physiological parameters in the three moments of evaluation with the Behavioral Pain Scale in patients hospitalized in a regional hospital of Vitória da Conquista, Bahia, Brazil, 2017

\begin{tabular}{|c|c|c|c|c|c|}
\hline \multirow[t]{2}{*}{ Groups } & \multirow[t]{2}{*}{ Parameters } & \multicolumn{3}{|c|}{ Mean \pm SD } & \multirow[t]{2}{*}{$\mathrm{p}$-value } \\
\hline & & At rest & Eye cleansing & Tracheal suction & \\
\hline \multirow[t]{4}{*}{ Group 1} & HR (bpm) & $88.7(26.6)$ & $89.9(26.4)$ & $104(29.1)$ & $<0.001$ \\
\hline & $\mathrm{SpO}_{2}$ in $\%$ & $97.3(4.0)$ & $97.3(3.8)$ & $95.0(4.9)$ & $<0.001$ \\
\hline & $\mathrm{SBP}(\mathrm{mmHg})$ & $122.3(29.4)$ & $122.3(28.9)$ & $139.8(38.5)$ & $<0.001$ \\
\hline & Temperature ${ }^{\circ} \mathrm{C}$ & $35.9(1.2)$ & $35.9(1.2)$ & $35.9(1.2)$ & 0.846 \\
\hline \multirow[t]{4}{*}{ Group 2} & HR (bpm) & $90.9(21.7)$ & $91.2(22.3)$ & $104.4(20.1)$ & $<0.001$ \\
\hline & RR (irpm) & $16.1(4.5)$ & $16.4(4.7)$ & $25.2(9.2)$ & $<0.001$ \\
\hline & $\mathrm{SpO}_{2}$ in $\%$ & $97.7(2.5)$ & $97.8(2.6)$ & $95.3(3.6)$ & $<0.001$ \\
\hline & Temperature ${ }^{\circ} \mathrm{C}$ & $35.7(1.1)$ & $35.7(1.1)$ & $35.7(1.1)$ & 0.717 \\
\hline
\end{tabular}


Table 3. Variation of the physiological parameters in the three moments of evaluation with the Behavioral Pain Scale in patients hospitalized in a regional hospital of Vitória da Conquista, Bahia, Brazil, 2017 - continuation

\begin{tabular}{|c|c|c|c|c|c|}
\hline \multirow[t]{2}{*}{ Groups } & \multirow[t]{2}{*}{ Parameters } & \multicolumn{3}{|c|}{ Mean \pm SD } & \multirow[t]{2}{*}{$p$-value } \\
\hline & & At rest & Eye cleansing & Tracheal suction & \\
\hline \multirow[t]{3}{*}{ Group 3} & $\mathrm{HR}$ (bpm) & $87.2(26.5)$ & $91.6(16.0)$ & $100.8(15.4)$ & $<0.001$ \\
\hline & $\mathrm{SpO}_{2}$ in $\%$ & $96.6(3.2)$ & $96.7(3.1)$ & $94.7(5.4)$ & 0.025 \\
\hline & $\mathrm{SBP}(\mathrm{mmHg})$ & $121.8(29.4)$ & $121.9(29.3)$ & $150.3(43.5)$ & 0,001 \\
\hline $\mathrm{DBP}(\mathrm{mmHg})$ & Temperature ${ }^{\circ} \mathrm{C}$ & $35.6(1.4)$ & $35.6(1.5)$ & $35.5(1.5)$ & 0.368 \\
\hline
\end{tabular}

Group 1 = sedation and analgesia; Group 2 = analgesia; Group 3 = no sedation or analgesia; $\mathrm{HR}=$ heart rate; $\mathrm{RR}=$ respiratory rate; SpO 2 = peripheral oxygen saturation; SBP = systolic blood pressure; DBP = diastolic blood pressure; MAP = mean arterial pressure. Data expressed as mean and standard deviation. *ANOVA test.

Table 4. Behavioral Pain Scale scores during the three times of scale application in patients hospitalized in a regional hospital, Vitória da Conquista, Bahia, Brazil, 2017

\begin{tabular}{|c|c|c|c|c|c|}
\hline \multirow[t]{2}{*}{ Groups } & \multirow[t]{2}{*}{ BPS Scores } & \multicolumn{3}{|c|}{ Mean \pm SD } & \multirow[t]{2}{*}{ p-value } \\
\hline & & At rest & Eye cleansing & Tracheal suction & \\
\hline \multirow[t]{4}{*}{ Group 1} & Facial expression & $1.1(0.3)$ & $1.1(0.4)$ & $2.1(0.9)$ & $<0.001$ \\
\hline & Upper limbs & $1.0(0.2)$ & $1.0(0.2)$ & $2.1(0.7)$ & $<0.001$ \\
\hline & Adaptation to mechanical ventilation & $1.0(0.1)$ & $1.0(0.1)$ & $2.0(0.3)$ & $<0.001$ \\
\hline & Total & $3.1(0.3)$ & $3.2(0.4)$ & $6.2(1.4)$ & $<0.001$ \\
\hline \multirow[t]{4}{*}{ Group 2} & Facial expression & $1.3(0.6)$ & $1.4(0.6)$ & $3.2(1.0)$ & $<0.001$ \\
\hline & Upper limbs & $1.1(0.3)$ & $1.1(0.3)$ & $2.8(1.0)$ & $<0.001$ \\
\hline & Adaptation to mechanical ventilation & $1.1(0.2)$ & $1.1(0.2)$ & $2.2(0.6)$ & $<0.001$ \\
\hline & Total & $3.4(1.0)$ & $3.6(1.0)$ & $8.2(2.4)$ & $<0.001$ \\
\hline \multirow[t]{4}{*}{ Group 3} & Facial expression & $1.3(0.7)$ & $1.4(0.7)$ & $2.7(0.9)$ & $<0.001$ \\
\hline & Upper limbs & $1.3(0.6)$ & $1.3(0.6)$ & $2.7(1.0)$ & $<0.001$ \\
\hline & Adaptation to mechanical ventilation & $1.1(0.2)$ & $1.1(0.2)$ & $1.9(0.4)$ & $<0.001$ \\
\hline & Total & $3.7(1.4)$ & $3.7(1.4)$ & $7.3(2.1)$ & $<0.001$ \\
\hline
\end{tabular}

Group 1 = sedation and analgesia; Group 2 = analgesia; Group 3 = no sedation or analgesia; Data expressed as mean and standard deviation. ${ }^{*}$ ANOVA test.

\section{DISCUSSION}

Pain control, even in critically unarticulated patients, is vital. However, despite the technological advances in the care of critical patients in emergency or intensive care units, pain assessment and its proper management have been poorly addressed. This study found that even for patients undergoing analgesia and sedation, there was variation in the physiological parameters and BPS scores when they underwent painful procedures, especially TS, a routine technique in hospital units. This implies flaws in the process of pain assessment and the adequacy of analgesia in patients in intensive care.

This ineffective control of pain is the result of a series of factors indicated in literature such as choosing an inadequate method of pain measurement, insufficient professional training or improper management of the pain without scientific evidence ${ }^{9,17,22,23}$. In addition, the resistance to change the routine of many professionals is also an important cause of inadequacies in the control of the pain in critical patients ${ }^{17}$.
Some studies have also pointed out the lack of knowledge of the professionals about scales with considerable accuracy to assess pain in unarticulated patients ${ }^{9,24}$. However, since it is not possible to obtain the patient's verbal report about his/her pain, several observational scales have been recommended ${ }^{12}$. Among them, the BPS stands out for its high accuracy, easy application and for being adapted to the Brazilian reality ${ }^{8,25}$.

Like other studies conducted in Brazil ${ }^{6,17,25}$, this study showed that the BPS was adequate to evaluate pain in unarticulated patients. The comparison of the scale scores at rest and during eye cleansing, considered as a non-painful procedure, showed no variation. In this study, eye cleansing simulates other situations or procedures that are performed by the professional, such as dressing changes and measure temperature, but which do not necessarily correspond to painful stimuli ${ }^{8,25,26}$. However, the results showed a significant variation in the scale scores during TS - considered a painful process for the patient - and the highest scores of the instrument were observed, regardless of the form of analgesia (or absence). 
Although the change in physiological parameters is not necessarily an indication to assess the pain in unarticulated patients, a significant variation in heart rate, respiratory rate, oxygen saturation, and systemic blood pressure was observed in the present study. These results are similar to those reported in other studies that analysed whether changes in BPS were accompanied by physiological changes in patients ${ }^{13,17}$. However, it is worth mentioning that the physiological parameters can be sensitive to several factors besides the presence of pain, such as fear, anxiety and psychological stressors ${ }^{6,7,9}$ and other clinical conditions. Thus, the monitoring of physiological parameters alone as a way to assess pain has not been recommended ${ }^{9,12,27-32}$, making necessary the use of properly validated scales/instruments and with proved accuracy, such as the BPS 9,33 .

The lowest BPS scores were found in group 1. However, even these patients showed significant variations in the scores of the pain scale, which implies that even in them the pain was being underestimated. Also, it was not possible to establish whether those in group 1 were experiencing less pain or if they were unable to present $\mathrm{it}^{8}$, as it would be unethical to conduct research involving the manipulation of sedation or analgesia levels since the patients would be exposed to a higher possibility of feeling pain ${ }^{17}$. Indeed, from the results of this study, it can be inferred that adjustments in pain control should be performed even in individuals with sedation and analgesia, which can be obtained with an accurate assessment of the pain in these patients.

Other studies show that behavioral indicators are more sensitive and present more adequate data than the hemodynamic parameters in the assessment of pain in critically ill patients ${ }^{29,33,34}$. However, the use of observational scales should not be considered as the most reliable or the only evaluation necessary since they do not reflect the intensity or the location of the pain, and they can be masked by deep sedation or the use of blocking agents. Likewise, these instruments should not replace the self-report of pain, when possible $e^{25,34}$.

\section{CONCLUSION}

Considering the observed aspects, we noticed an intense pain during TS, visualized by the elevation of the BPS scores in all the groups observed, confirming their responsiveness. Despite the alteration of the physiological parameters during the observation of groups 1 and 2, the same did not happen in group 3, indicating that the hemodynamic alterations should not be used as valid precursors to measure the pain.

\section{REFERENCES}

1. Silva JA, Ribeiro-Filho NP. A dor como um problema psicofísico. Rev Dor. 2011;12(2):138-51.

2. Koppert W. [Acute pain therapy in pediatrics and geriatrics - pain assessment and treatment options]. Anasthesiol Intensivmed Notfallmed Schmerzther. 2011;46(5):332-3. German.

3. Puntillo KA, White C, Morris AB, Perdue ST, Stanik-Hutt J, Thompson CL, et al. Patients' perceptions and responses to procedural pain: results from Thunder Project II. Am J Crit Care. 2001;10(4):238-51.

4. Puntillo KA, Morris AB, Thompson CL, Stanik-Hutt J, White CA, Wild LR. Pain behaviors observed during six common procedures: results from Thunder Project II*. Crit Care
Med. 2004;32(2):421-7

5. Alert AP. Assessing pain in the critically ill adult. Critical Care Nurse. 2014;34(1):81-3.

6. Azevedo-Santos IF, Alves IG, Badauê-Passos D, Santana-Filho VJ, DeSantana JM. Psychometric analysis of Behavioral Pain Scale Brazilian version in sedated and mechanically ventilated adult patients: a preliminary study. Pain Pract. 2016;16(4):451-8.

7. Gélinas C, Chanques G, Puntillo K. In pursuit of pain: recent advances and future directions in pain assessment in the ICU. Intensive Care Med. 2014;40(7):1009-14.

8. Chen HJ, Chen YM. Pain assessment: validation of the physiologic indicators in the ventilated adult patient. Pain Manag Nurs. 2015;16(2):105-11.

9. Ferreira N, Miranda C, Leite A, Revés L, Serra I, Fernandes AP, et al. Dor e analgesia em doente crítico. Rev Clin Hosp Prof Dr. Fernando Fonseca. 2014;2(2):17-20.

10. Herr K, Coyne PJ, McCaffery M, Manworren R, Merkel S. Pain assessment in the patient unable to self-report: position statement with clinical practice recommendations. Pain Manag Nurs. 2011;12(4):230-50.

11. IASP. Paint Terms, A Current List with Definitions and Notes on Usage. In: Merskey H, Bogduk N, editor(s). Classification of Chronic Pain, Seattle: IASP Press. 2012;209-14.

12. Gelinas C. Nurses' evaluations of the feasibility and the clinical utility of the critical-care pain observation tool. Pain Manag Nurs. 2010;11(2):115-25.

13. Payen JF, Bru O, Bosson JL, Lagrasta A, Novel E, Deschaux I, et al. Assessing pain in critically ill sedated patients by using a behavioral pain scale. Crit Care Med. 2001;29(12):2258-63.

14. Morete MC, Mofatto SC, Pereira CA, Silva AP, Odierna MT. Translation and cultural adaptation of the Brazilian Portuguese version of the Behavioral Pain Scale. Rev Bras Ter Intensiva. 2014;26(4):373-8.

15. Sessler CN, Pedram S. Protocolized and target-based sedation and analgesia in the ICU. Crit Care Clin. 2009;25(3):489-513.

16. Dehghani $\mathrm{H}$, Tavangar $\mathrm{H}$, Ghandehari A. Validity and reliability of behavioral pain scale in patients with low level of consciousness due to head trauma hospitalized in intensive care unit. Arch Trauma Res. 2014;3(1):e186084.

17. Sakata RK. Analgesia and sedation in intensive care unit. Rev Bras Anestesiol. 2010;60(6):648-58.

18. Gélinas C. Pain assessment in the critically ill adult: recent evidence and new trends. Intensive Crit Care Nurs. 2016;34:1-11.

19. http://www.igh.org.br/index.php/contratos-igh/23-vitoria-da-conquista-ba/25-servic-o-de-enfermagem-na-emerge-ncia-do-hgvc. Acesso em 17 de outubro de 2017.

20. Ahlers SJ, van der Veen AM, van Dijk M, Tibboel D, Knibbe CA. The use of the Behavioral Pain Scale to assess pain in conscious sedated patients. Anesth Analg. 2010;110(1):127-33.

21. Robleda G, Roche-Campo F, Membrilla-Martínez L, Fernández-Lucio A, Villamor Vázquez M, Merten A, et al. [Evaluation of pain during mobilization and endotracheal aspiration in critical patients]. Med Intensiva. 2016;40(2):96-104. Spanish.

22. Gélinas C, Arbour C, Michaud C, Vaillant F, Desjardins S. Implementation of the critical-care pain observation tool on pain assessment/management nursing practices in an intensive care unit with nonverbal critically ill adults: a before and after study Int J Nurs Stud. 2011;48(12):1495-504.

23. Dale J, Bjørnsen LP. Assessment of pain in a Norwegian Emergency Department. Scand J Trauma, Resusc Emerg Med. 2015;23:86.

24. Ribeiro MC, Pereira CU, Sallum AM, Santos AC, Nunes MS, Alves JA. Characteristics of pain in trauma victims at an emergency service. J Nurs UFPE on line, 2012;6(4):720-7.

25. Azevedo-Santos IF, Alves IG, Cerqueira Neto ML, Badauê-Passos D, Santana-Filho VJ, Santana JM. [Validation of the Brazilian version of Behavioral Pain Scale in adult sedated and mechanically ventilated patients]. Rev Bras Anestesiol. 2017;67(3):271-7.

26. Ribeiro CJ, Bezerra DS, Lima AG, Fernandes CC, Menezes MG, Ribeiro MC. Pain during tracheal aspiration in patients with traumatic brain injury undergoing mechanical ventilation. Rev Dor. 2017;18(4):332-7.

27. De Jong A, Molinari N, de Lattre S, Gniadek C, Carr J, Conseil M, et al. Decreasing severe pain and serious adverse events while moving intensive care unit patients: a prospective interventional study (the NURSE-DO project). Crit Care. 2013;17(2):R74.

28. Chen YY, Lai YH, Shun SC, Chi NH, Tsai PS, Liao YM. The Chinese Behavior Pain Scale for critically ill patients: translation and psychometric testing. Int J Nurs Stud. 2011;48(4):438-48.

29. Kapoustina O, Echegaray-Benites C, Gélinas C. Fluctuations in vital signs and behavioura responses of brain surgery patients in the Intensive Care Unit: are they valid indicators of pain? J Adv Nurs. 2014;70(11):2562-76.

30. Gélinas C, Johnston C. Pain assessment in the critically ill ventilated adult: validation of the critical-care pain observation tool and physiologic indicators. Clin J Pain. 2007;23(6):497-505.

31. Gélinas C, Arbour C. Behavioral and physiologic indicators during a nociceptive procedure in conscious and unconscious mechanically ventilated adults: similar or different? J Crit Care. 2009;24(4):628.e7-17.

32. Arbour C, Gélinas C. Behavioral and physiologic indicators of pain in nonverbal patients with a traumatic brain injury: an integrative review. Pain Manag Nurs. 2014;15(5):506-18.

33. Barr J, Fraser GL, Puntillo KA, Ely EW, Gélinas C, Dasta JF, et al. Clinical practice guidelines for the management of pain, agitation, and delirium in adult ICU patients. Crit Care Med. 2013;41(1):263-306.

34. Gélinas C, Tousignant-Laflamme Y, Tanguay A, Bourgault P. Exploring the validity of the bispectral index, the critical-care pain observation tool and vital signs for the detection of pain in sedated and mechanically ventilated critically ill adults: a pilot study. Intensive Crit Care Nurs. 2011;27(1):46-52. 